\title{
原著
}

\section{Sorbose の基質としての满蝕原性*}

\author{
Cariogenicity of Sorbose as a Substrate
}

\author{
平澤 正 知** 竹 内武 男 ${ }^{* *}$ 佐 藤 晴 彦** \\ 清 水俊 雄 ${ }^{* * *}$ 池田 正 ${ }^{* *}$ \\ Masatomo HIRASAWA **, Takeo TAKEUCHI ${ }^{* *}$, Haruhiko SATOH ${ }^{* *}$, \\ Toshio SHIMIZU ${ }^{* * *}$ and Tadashi IKEDA **
}

Received March 26, 1990 ; accepted June 13, 1990

\begin{abstract}
Sorbose is a 2-ketohexose, differing from fructose in configuration at C-3 and C-4. It is obtained through a cultivation of sorbitol and Gluconobacter (Acetobacter) suboxydans. The sugar is about $80 \sim 90 \%$ as sweet as sucrose and is also non-hygroscopic. The effect of sorbose on the cariogenicity of mutans streptococci (serotype $a \sim h$ ) and certain oral microorganisms was studied. Sorbose was not utilized as a substrate for the growth, lactic acid production, and plaque formation of mutans streptococci (serotype $a \sim h$ ). It did not serve as a substrate for cellular aggregation of mutans streptococci and was not utilized in water-insoluble glucan synthesis and cellular adherence by glucosyltransferase from Streptococcus mutans PS-14 (c) or S. sobrinus $6715(\mathrm{~g})$. Sorbose was also not utilized for the growth and lactic acid production of certain oral microorganisms although some growth was seen with Lactobacillus casei and L. acidophilus. Two groups of SPF SD rats infected with $S$. mutans PS-14 were fed with a diet containing $30 \%$ sorbose and $30 \%$ sucrose for 58 days. A significantly $(p<0.01)$ lower caries score (mean $\pm \mathrm{SE} ; 17.5 \pm 2.0)$ was obtained in the rats fed with a diet containing $30 \%$ sorbose than in the rats fed with a diet containing $30 \%$ sucrose $(82.1 \pm 4.4)$. The caries inhibition rate was $78.7 \%$.
\end{abstract}

索引用語 : ソルボース, 低敬触原性糖, 代替甘味料, ストレプトコッカスミュータンス

Koy words: Sorbose, Low-cariogenic sugar. Sugar substitute, Streptococcus mutans

緒言

砂糖の主成分である sucrose に代表される糖類（基

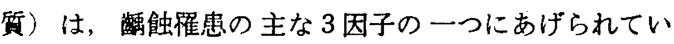

る。特に触の主要原因菌である Streptococcus mutans (S. mutans) の特徵的な数触原性作用は sucrose に依存している1,2)。さらに sucrose は蒾垢細菌による 酸生成の基啠となる。S. mutans を始めとする歯垢細菌

* 本論文の要旨は，第67回 IADR Annual Meeting（1989年）において発表した。

** 日本大学松戸齿学部細菌学教室（主任：池田 正）

** Department of Microbiology, Nihon University School of Dentistry at Matsudo (chicef: Prof. Tadashi IKEDA)

***旭化成工業（株）食品技術研究室

*** Asahi Chemical Industry Co. Foods Research Laboratory 
の解触原性発揮に，基啠として利用されない sucrose 代 替甘味料の使用は，触予防に有効な一手段である。加 えて, その使用には尃門的知践や専門家の手を煩わせな いで実施できる大きな利点がある。この見地から当教 室 ${ }^{8-13)}$ では, 触の原因となりにくい sucrose 代替甘味 料の検索と開発について一連の研究を行っており, それ らの数種はすでに実用化されている。

現在，非・低螎蝕原性糖類として糖アルコール類の sorbitol $^{14-18)}, x^{2}$ litol $^{7,15,17)}$, maltitol $^{8,6,18)}$, erythritol ${ }^{12)}$ など, 少糖類の coupling sugar ${ }^{4}$, fructooligosaccharide $^{(3)}$, palatinose ${ }^{19,20)}$ など, および配糖体の stevioside ${ }^{5)}$ などがある。それらは蝕原性を含め砂糖がもつ 医学的欠点のいくつかは改善されているが，甘味の犋, 甘味度, 価格あるいは食品工業的理由などで砂糖と比較 すれば多少なりとも劣る面がある。したがって用途はあ る程度限定されているのが現状であり, より良い代替甘 味料の開発が望まれている。

本研究は, fructose の異性体で ketohexose の一種で ある sorbose について, 現在の触病因論に基つきその 基梊としての䚚触原性を追究した。天然の sorbose は Sorbus aucuparia の成熟果実に含まれる sorbitol が, 同果実に増殖する 数種の 細菌 ${ }^{21)} の$ 脱水素化作用により sorbose となり存在している。工業的には sorbitol を原 料として Gluconobacter (Acetobacter) suboxydans $の$ 発醉作用によりつくられ，テイリングのない良犋の甘味 をもち，その甘味度は sucrose の80 90\%で吸湿性のな い白色無臭の熱に安定な結晶体である。

\section{材料と方法}

\section{1. 供試 sorbose}

旭化成工業（株）食品技術研究室から提供された純度 99\%以上の L-sorbose を標品として使用した。

\section{2. 使用菌株と培地}

教室保存の S. mutans 群 : S. cricetus OMZ-61 (血 清型 a), S. rattus BHT (b), S. mutans PS-14 (c), LM-7 (e), OMZ-175 $(f)$, S. sobrinus OMZ-176 (d), $6715(g)$, serotype “ $h$ ” $11391(h)$, および口腔細菌 7 菌種: S. sanguis ATCC 10556, S. mitior NCTC 3168, S. salivarius ATCC 9222, Lactobacillus casei ATCC 4646, L. acidophilus ATCC 4962, Actinomyces viscosus ATCC 19246, A. naeslundii ATCC 12104を使用した。培地は実験目的によって半合成培地 $\mathrm{M4}^{22)}$, trypticase soy broth (Becton-Dickinson) から glucose を除いた組成（TSB-GF）に供試基啠を加えた
培地, brain heart infusion (BHI, Difco) および Mitis Salivarius 寒天（MS 寒天, Difco）を用いた。 嫌気培養は $\mathrm{N}_{2} 95 \%, \mathrm{CO}_{2} 5 \%$ のガス圈換法で行った。 供試菌はすべて BHIに18時間嫌気前培養してから使用 した。

\section{3. 実験方法}

1）人工歯垢形成。供試菌液 $0.05 \mathrm{~m} l$ を，あらかしめ 重量測定してある試験管を用いて $5 \%$ sucrose または 5 $\%$ sorbose 加 $\mathrm{BHI} 5 \mathrm{~m} l$ に移植し，嫌気培趇した。24 時間ごとに新しい同培地と交換し，4 日後に管壁に付着 している菌体を蒸留水で 3 回洗浄後, $80^{\circ} \mathrm{C}$ で 5 時間乾 燥し重量測定を行い歯垢量を求めた。

2）菌体凝集。Ikeda ${ }^{28)}$ らの方法に準して行った。供 試菌を M4 培地に18時間嫌気培養し, 遠沈に上る収集 菌体を $0.8 \%$ 生食水で 3 回洗浄後, $0.2 \mathrm{M}$ glycine- $\mathrm{NaOH}$ 楥衝液 ( た。菌液 $0.4 \mathrm{~m} l に 1 \mathrm{mg} / \mathrm{m} l$ の sorbose または dextran T2000 (Pharmacia Fine Chemicals Inc.) $0.2 \mathrm{ml}$ 混 和し，ミキサー（サーモニクス KK, TM-100）で傮拌 後 $37^{\circ} \mathrm{C}$ の恒温槽中でインキュベートし，18時間後の菌 体凝集性を観察した。結果は0（無疑集）から4（最大 凝集)の 5 段階で判定した。

3）乳酸生成。供試菌の BHI 18時間嫌気培養菌体を 遠沈で収集し，0.05M phosphate 緩衝液 $(\mathrm{pH} \mathrm{6.8)}$ ) 洗浄後, 同緩衝液で菌浮遊液 $\left(5 \times 10^{8}\right.$ colony forming unit $/ \mathrm{m} l)$ とした。その $0.5 \mathrm{~m} l, 1 \%$ 基犋溶液 $0.2 \mathrm{~m} l, 22.5$ $\mathrm{mM} \mathrm{MgCl} 20.4 \mathrm{ml}, 0.2 \mathrm{M}$ phosphate 㣪衙液 $(\mathrm{pH} \mathrm{6.8)}$ $0.9 \mathrm{~m} l$ からなる反応液を, $37^{\circ} \mathrm{C}$ の恒温槽中で 30 分間振 盕インキュベートし, $100^{\circ} \mathrm{C} 10$ 分間の加熱により反応停 止後, 遠沈してその上清の乳酸量を醭素法24) (LactateUV-test, ベーリンガー・マンハイム山之内）で定量し た。

4) glucosyltransferase（GTase）の調製と非水溶性 glucan 生成およびその阻害。Fukushima ら222の方法に 準して行った。供試菌を $\mathrm{M} 4$ 培地に $37^{\circ} \mathrm{C} 20$ 時間好気培 荺し，遠沈後その上清の $40 \%$ cold ethanol 沈殿物を， $5 \mathrm{mM}$ triethanolamine 液 $(\mathrm{pH}$ 9.0) に透析して得た可 溶性画分を，粗 GTase として使用した。PS-14 株の GTase 標品は0.7 $\mu \mathrm{mole} / \mathrm{min} / \mathrm{ml}, 6715$ 株の同標品は0.5 $\mu \mathrm{mole} / \mathrm{min} / \mathrm{m} l$ の glucose 転移活性を示した。

非水溶性 glucan 量の測定は 2 種の方法で行った。連 続濁度法は，GTase 液100 $\mu l ， 0.15 \mathrm{M}$ sucrose または sorbose $100 \mu l, 0.6 \mathrm{M}$ acetate 楥衝液 (pH 5.5) $50 \mu l$, 非 水溶性 glucan プライマー $(0.2 \mathrm{mg} / \mathrm{m} l) 50 \mu l$ からなる 
反応液を, $25^{\circ} \mathrm{C}$ に保温した分光光度計（日立136型）の ミクロセル内で反応させ, 非水溶性 glucan 生成に伴う $340 \mathrm{~nm}$ の吸光度変化を記録した。生成量は, 反応パター ンの直線部分の吸光度変化量 $(\Delta 340 \mathrm{~nm} / \mathrm{min})$ より, 1 分間あたり生成される非水溶性 glucan GTase が作る非水溶性 glucan の検量線から算出し， glucose 当量として示した。また，上記反応液を $37^{\circ} \mathrm{C} 24$ 時間インキュベートし，遠沈による沈渣を蒸留水で 3 回 洗浄後、フェノール硫酸法25) で測定する方法でも行っ た。非水溶性 glucan 生成阻害実験では, 所要瀑度の sorbose sucrose 溶液に混和したものを基所液として 使用した。

5） ${ }^{3} \mathrm{H}$ 標識菌体の調製と菌体付着およびその阻害。 ${ }^{3} \mathrm{H}$ 標識菌体の調製は, Schachtele ら ${ }^{28)}$ の方法を改変し た Ikeda ら 28)の方法に準して行った。 $92.5 \mathrm{kBq} / \mathrm{ml} の$ [4.5. $\left.{ }^{8} \mathrm{H}(\mathrm{N})\right]-\mathrm{L}-$ leucine を含む M4 培地に, 供試菌を $37^{\circ} \mathrm{C}$ 18時間好気培養し，遠沈による収集菌体を $0.05 \mathrm{M}$ phosphate 楥衙液 ( $\mathrm{pH}$ 6.8) で 3 回洗浄後 $100^{\circ} \mathrm{C} 15$ 分間 加熱して死菌体とした。これを $0.2 \%$ sodium merthiolate を含む同楥衙液に慜濁し，濁度1.0 ( A $\left._{540 \mathrm{~nm}}\right)$ の菌浮遊夜とした。 ${ }^{3} \mathrm{H}$ 標識菌液 $200 \mu l$ と GTase 液, $0.15 \mathrm{M}$ 基梊液および $0.2 \%$ に sodium merthiolate を含 む0.05M phosphate 㣪衍液各 $100 \mu l$ を mini screw cap

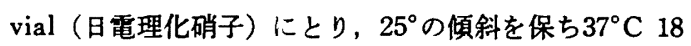
時間インキュベートした。vial 壁に付着していない菌体 を吸引除去し, 付着菌体を蒸留水で 3 回洗浄後乾燥し, Bray's scintillation fluid ${ }^{27)}$ を加えて放射活性を測定し た。その値から GTase を含まない反応液で付着した菌 体の放射活性值を差し引き，基所依存付着菌体盟を求め た。

6）ラット触。生後18日龄の JCL - Sprague-Dawley ラット（雄）を強制離乳させて 3 群に別け，A群は diet $2000^{28)}$ の $56 \%$ sucrose を56\% starch に，B群は同 ヒく26\% starch と30\% sucrose に，C群は $26 \%$ starch と30\% sorbose に置き換えた飼料で飼育した。18日龄か らの 3 日間は, 各群の飼料に carbenicillin (藤沢薬品), ampicillin (明治製菓) および chloramphenicol（三共 製薬）を各 $1 \mathrm{~g} / \mathrm{kg}$ に添加して与え，口腔常在菌の㧕制 を行った。22日龄に, streptomycin 耐性 $(10 \mathrm{mg} / \mathrm{ml})$ の S. mutans PS-14株をラット口腔に感染し, 翌日 streptomycin $(1 \mathrm{mg} / \mathrm{m} l)$ 加 MS 寒天で感染菌の口腔内定着 を確認した。未定着ラットは定着するまで同操作を綝り 返した。76日龄に屠殺し, Ikeda ら ${ }^{281}$ の方法により下影 の触スコアを測定した。

\section{結 果}

1. S. mutans 群と他の口腔細菌の発育への利用性

$0.5 \%$ glucose を炭素源とする半合成培地 M4と, glucose の代わりに同摆度 sorbose を加えた培地に, $S$. mutans 群血清型 $b \sim h$ の 7 菌株を18時間好気培趇した 結果と, S. cricetus ( $a$ 型) 菌株, Lactobacillus 属菌, Actinomyces 属菌は M4培地に発育不良なため, TSB. GF に同湌度の glucose または sorbose を加えた培地 に供試菌株を嫌気培養し, それらの発育度を glucose と 比校した結果を Table 1 に示した。 sorbose は供試した S. mutans 群のすべての血清型菌株によって, 発育のた めの炭素源として利用されなかった。また供試した Lactobacillus 属菌株は多少の発育を慧めたが, Actinomyces 属菌および S. mutans 群以外の Streptococcus 属菌の各菌株により発育には利用されなかった。

Table 1 Utilization of sorbose for growth of oral microorganisms

\begin{tabular}{|c|c|c|c|}
\hline \multirow{2}{*}{ Microorganism } & \multirow{2}{*}{$\underset{\text { (serotype) }}{\text { Strain }}$} & \multicolumn{2}{|c|}{ Growth (A $540 \mathrm{~nm})$} \\
\hline & & Glucose & Sorbose \\
\hline \multicolumn{4}{|l|}{ Streptococcus } \\
\hline S. cricetus & OMZ-61 (a) & 0.70 & 0.00 \\
\hline S. rattus & BHT $\quad(b)$ & 1.09 & 0.02 \\
\hline S. mutans & PS-14 (c) & 1.19 & 0.00 \\
\hline S. sobrinus & $\mathrm{OMZ}-176(d)$ & 1.05 & 0.01 \\
\hline S. mutans & LM-7 & 1.40 & 0.00 \\
\hline S. mutans & $\mathrm{OMZ}-175(f)$ & 1.40 & 0.00 \\
\hline S. sobrinus & 6715 & 1.10 & 0.01 \\
\hline$S$. serotype " $h$ " & 11391 & 1.30 & 0.01 \\
\hline S. salivarius & 9222 & 1.10 & 0.00 \\
\hline S. sanguis & 10556 & 1.15 & 0.00 \\
\hline S. mitior & 3168 & 1.10 & 0.00 \\
\hline \multicolumn{4}{|l|}{ Lactobacillus } \\
\hline L. casei & 4646 & 0.99 & $0.58(0.05)$ \\
\hline L. acidophilus & 4962 & 0.88 & $0.45(0.27)$ \\
\hline \multicolumn{4}{|l|}{ Actinomyces } \\
\hline A. viscosus & 19246 & 1.05 & $0.40(0.40)$ \\
\hline A. naeslundii & 12104 & 1.10 & $0.48(0.48)$ \\
\hline
\end{tabular}

Aerobic incubation in defined medium M4 containing $0.5 \%$ substrate for $18 \mathrm{hr}$, except $S$. cricetus, Lactobacillus and Actinomyces (used trypticase soy broth without glucose containing $0.5 \%$ substrate).

Each value represents mean of duplicate ( ) : no substrate added. 
Table 2 Utilization of sorbose for plaque formation of mutans streptococci

\begin{tabular}{lccc}
\hline \multirow{2}{*}{$\begin{array}{c}\text { Strain } \\
\text { (serotype) }\end{array}$} & \multicolumn{2}{c}{ Plaque (mg, dry weight) } \\
\cline { 3 - 4 } & Sucrose & Sorbose \\
\hline OMZ-61 & $($ a $)$ & 36.5 & 0.6 \\
BHT & $(b)$ & $0.0^{*}$ & 0.0 \\
PS-14 & $(c)$ & 57.5 & 0.2 \\
OMZ-176 & $(d)$ & 50.5 & 0.2 \\
LM-7 & $($ e $)$ & 24.4 & 0.5 \\
OMZ-175 & $(f)$ & 20.3 & 0.1 \\
6715 & $(g)$ & 36.4 & 0.1 \\
11391 & $(h)$ & 53.5 & 0.0 \\
\hline
\end{tabular}

Each strain was incubated in BHI containing either $5 \%$ sucrose or $5 \%$ sorbose and anaerobically incubated at $37^{\circ} \mathrm{C}$ with the medium being replaced by a fresh one daily for 4 days and the adherent material measured.

Each value represents mean of duplicate

* This BHT strain does not form plaque

Table 3 Utilization of sorbose for cellular aggregation of certain mutans streptococci

\begin{tabular}{llcc}
\hline \multirow{2}{*}{$\begin{array}{c}\text { Strain } \\
\text { (serotype) }\end{array}$} & \multicolumn{2}{c}{ Aggrgeation* } \\
\cline { 3 - 4 } & Dextran & Sorbose \\
\hline OMZ-176 & $($ d $)$ & +4 & 0 \\
6715 & $(g)$ & +4 & 0 \\
11391 & $(h)$ & +4 & 0 \\
\hline
\end{tabular}

* Results were scored 0 (no aggregation) to 4 (maximum aggregation)

\section{2. 人工歯垢形成一の利用性}

S. mutans 群の in vitro における歯垢形成に, sorbose が基質として利用されるかを実兒した結果を Table 2 に示した。対照基啠として用いた sucrose 例で は, 供試菌株によって量的にかなりの差を示している が, BHT 株を除く各血清型菌株は20.3 $57.5 \mathrm{mg}$ の人 工歯垢を形成した。しかし, sorbose では各血清型菌株 とも明らかな齒垢形成を認めなかった。

\section{3. 菌体凝集作用}

S. mutans 群の菌体凝集に sorbose が基質として利用 されるかを, 血清型 $d, g, h$ 菌株を用いて実験した結 果を Table 3 に示した。対照として用いた dextran に よって供試各菌株は明らかな菌体凝集を認めたが， sorbose では各菌株ともに菌体凝集を 全く認めなかった。
Table 4 Production of lactic acid from sorbose by oral microorganisms

\begin{tabular}{|c|c|c|c|}
\hline \multirow{2}{*}{ Microorganism } & \multirow{2}{*}{$\underset{\text { (serotype) }}{\text { Strain }}$} & \multicolumn{2}{|c|}{$\begin{array}{l}\text { Lactic acid } \\
(\mu \text { mole } / \mathrm{ml})\end{array}$} \\
\hline & & Glucose & Sorbose \\
\hline \multicolumn{4}{|l|}{ Streptococcus } \\
\hline S. cricetus & $\mathrm{OMZ}-61 \quad(a)$ & 3.6 & 0.0 \\
\hline S. rattus & $\mathrm{BHT} \quad(b)$ & 4.2 & 0.0 \\
\hline S. mutans & PS-14 (c) & 3.5 & 0.0 \\
\hline S. sobrinus & $\mathrm{OMZ}-176(d)$ & 3.4 & 0.0 \\
\hline S. mutans & $\mathrm{LM}-7 \quad(e)$ & 3.8 & 0.0 \\
\hline S. mutans & $\mathrm{OMZ}-175(f)$ & 3.6 & 0.0 \\
\hline S. sobrinus & 6715 & 3.6 & 0.0 \\
\hline$S$. serotype " $h$ " & 11391 & 3.3 & 0.0 \\
\hline S. salivarius & 9222 & 3.7 & 0.0 \\
\hline S. sanguis & 10556 & 3.4 & 0.0 \\
\hline S. mitior & 3168 & 3.9 & 0.0 \\
\hline \multicolumn{4}{|l|}{ Lactobacillus } \\
\hline L. casei & 4646 & 3.5 & 0.0 \\
\hline L. acidophilus & 4962 & 3.1 & 0.0 \\
\hline \multicolumn{4}{|c|}{ Actinomyces } \\
\hline A. viscosus & 19246 & 0.7 & 0.0 \\
\hline A. naeslundii & 12104 & 0.8 & 0.0 \\
\hline
\end{tabular}

Each value represents mean of duplicate

4. 乳酸生成人の利用性

S. mutans 群による sorbose からの乳酸生成を実験 した結果を Table 4 に示した。S. mutans 群各血清型 菌株の glucose を基斦としたときの乳酸生成量は3.3 $4.2 \mu \mathrm{mole} / \mathrm{ml}$ であったが, sorbose からは全く慧められ なかった。同様に供試した Streptococcus 属菌, Lactobacillus 属菌およひ Actinomyces 属菌の各菌株による 同標品からの乳酸生成も全く羿められなかった。なお, S. mutans などは菌体内貯藏多糖 (intracellular polysaccharaide）を保有し，それによる内因性の酸産生が少 量認められるので, 基啠無添加系の反応液の值を基梊添 加系の测定値から引き実験值として表示した。

5. 非水溶性 glucan 生成と菌体の平滑面付着への利 用性

Table 5 は, sorbose が非水溶性 glucan 生成に基兵 として 利用されるかを 2 種の実験方法で測定した 結果 と, S. mutans PS-14 株および $S$. sobrinus 6715株菌体 の平滑面付着に対する sorbose の利用性を, sucrose と 比較した結果である。

非水溶性グルカン生成は S. mutans PS-14株および S. sobrinus 6715 株より調製した GTase を用い，供試 
Table 5 Utilization of sorbose for water-insoluble glucan formation and cellular adherence by GTase from $S$. mutans or $S$. sobrinus

\begin{tabular}{|c|c|c|c|c|c|c|}
\hline \multirow{3}{*}{$\begin{array}{c}\text { GTase } \\
\text { Source } \\
\text { (serotype) }\end{array}$} & \multicolumn{4}{|c|}{ Insoluble glucan synthesis } & \multirow{2}{*}{\multicolumn{2}{|c|}{$\begin{array}{l}\text { Cell adherence* } \\
(\mathrm{Bq} \pm \mathrm{SE})\end{array}$}} \\
\hline & \multicolumn{2}{|c|}{$\mu$ mole glucose $/ \min \times 10^{-2}$} & \multicolumn{2}{|c|}{$\mu \mathrm{g}$ glucan $/ 24 \mathrm{~h}$} & & \\
\hline & sucrose & sorbose & sucrose & sorbose & sucrose & sorbose \\
\hline PS-14 (c) & 3.0 & 0 & 48.0 & 0 & $179.8 \pm 5.4$ & 0.0 \\
\hline $6715 \quad(g)$ & 3.5 & 0 & 55.0 & 0 & $1203.2 \pm 43.3$ & 0.0 \\
\hline
\end{tabular}

* Radioactivity of cells adhering to the glass surface without GTase was subtracted from the result. Each value of insoluble glucan synthesis represents mean of duplicate.

Table 6 Inhibition of sucrose-dependent insoluble glucan formation and cellular adherence caused by sorbose

\begin{tabular}{llccc}
\hline GTase & Condition & Insoluble glucan synthesis & & Cell adherence* \\
\cline { 3 - 3 } Source & & $\mu$ mole glucose $/ \mathrm{min} \times 10^{-2}$ & & $\mathrm{~Bq} \pm \mathrm{SE}$ \\
\hline \multirow{3}{*}{ PS-14 } & sucrose & 3.0 & $2.7[10.0]$ & $179.8 \pm 5.4$ \\
& sucrose + sorbose $(1: 1)$ & $2.5[16.7]$ & & $169.1 \pm 4.4[6.0]$ \\
& sucrose + sorbose $(1: 2)$ & $2.2[26.7]$ & $145.7 \pm 10.8[19.0]$ \\
& sucrore + sorbose $(1: 4)$ & 3.5 & $1203.2 \pm 43.3$ \\
& sucrose & $3.5[0.0]$ & $1103.4 \pm 50.1[8.3]$ \\
& sucrose + sorbose $(1: 1)$ & $3.0[14.3]$ & $1096.8 \pm 17.2[8.8]$ \\
& sucrose + sorbose $(1: 2)$ & $2.8[20.0]$ & $956.9 \pm 53.7[20.5]$ \\
\hline
\end{tabular}

[ ] inhibition, \%

* Radioactivity of cells adhering to the glass surface without GTase was subtracted from the result.

Each value of insoluble glucan synthesis represents mean of duplicate.

基澌からの非水溶性 glucan 生成を連続濁度法で測定し た結果, 基質が sucrose では PS-14 株酵素で 1 分間当 たり $0.030 \mu \mathrm{mole}$ (glucose 当量)，6715 株酵秦では, $0.035 \mu$ mole (同) の非水溶性 glucan を検出したが, sorbose では両菌株酵素例とも全くその生成を琶めなか った。反応液のインキュベーションを24時間と延長し, 生成される非水溶性 glucan をフェノール硫酸法で定量

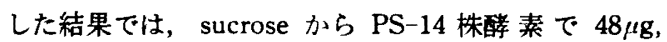
6715株醭素で $55 \mu \mathrm{g}$ の非水溶性 glucan を検出したが, sorbose では両菌株酵素例とも検出されなかった。菌体 の平滑面付着への利用性は GTase, ${ }^{3} \mathrm{H}$ ラベル加熱死 菌体, sucrose または sorbose などからなる反応液を screw cap vial 中で約25度の傾斜を保ち一昼夜インキ ュペート後, 管壁に付着した菌体量を放射活性から求め たものである。なお，第 2 対照である GTase 無添加の 反応系の测定值を，第 1 対照の sucrose 添加系および sorbose 添加系の测定值から引き実験值として示した。 sucrose を基梊としたレきPS-14 株および6715 株醇素 例とも大量の菌体付着を認めたが, sorbose では雨醳素 例とも菌体付着は認められなかった。

6. 非水溶性 glucan 生成および菌体付着の抑制

PS-14株および6715株の GTase による sucrose から の非水溶性 glucan 生成, および本菌の sucrose 依存菌 体付着におよぼす sorbose の影整を実験した結果を Table 6 に示した。Table 5 の実験に用いた内容と同 じ両反応液に，基啠として添加した sucrose 液にその同 量から 4 倍量の sorbose を追加混和した実験で, 非水溶 性 glucan 生成阻害が最高に認められたのは 4 倍量添加 の PS-14 株酵素例であり, その阻害率は sucrose 単独 の $26.7 \%$ あった。菌体付着阻害においても，最高を認 めたのは両酵素とも 4 倍量添加例で $20 \%$ 程度であった。 したがって, sorbose はそれらに対する顕著な阻害を示 さなかった。

7. ラット龋強実験 
Table 7 Caries scores of SPF SD rats infected with S. mutans PS-14 (c) and fed with a diet containing sorbose or sucrose for 58 days

\begin{tabular}{cccccccc}
\hline \multirow{2}{*}{ Group } & \multirow{2}{*}{ Diet } & \multirow{2}{*}{$\begin{array}{l}\text { No. } \\
\text { of }\end{array}$} & & \multicolumn{4}{c}{ Mean caries score (mandible) } \\
\cline { 6 - 8 } & & rat & Buccal & Sulcal & Approximal & Total \\
\hline A & $56 \%$ starch & 12 & 0 & $8.3 \pm 2.4$ & 0 & $8.3 \pm 2.4$ \\
B & $26 \%$ starch $+30 \%$ sucrose & 12 & $8.4 \pm 2.2$ & $71.9 \pm 2.6$ & $1.8 \pm 0.8$ & $82.1 \pm 4.4$ \\
C & $26 \%$ starch $+30 \%$ sorbose & 16 & $0.4 \pm 0.4$ & $17.1 \pm 1.9$ & 0 & $17.5 \pm 2.0$ \\
\hline
\end{tabular}

Values for buccal, sulcal and mean total from group C are significantly less $(p<0.01)$ than those from group $B$.

ラットに S. mutans PS-14株を経口感染させ, diet 2000の56\% sucrose をA群は同量の starch で（第 2 対 照)，B群は26\% starch と30\% sucrose で (第 1 対照)， C群は26\% starch と30\% sorbose で，それぞれ㯰き換 えた饲料で58日間飼育した下䫂の群別平均触スコアと 標準誤差を, Table 7 と Fig. 1 に示した。第 1 対照で ある sucrose 加飼料の B群における平均既触スコアは㛝

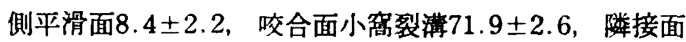
$1.8 \pm 0.8$ で合計 $82.1 \pm 4.4$ と高い傎を示した。sorbose 加飼料の C 群は 煩側平滑面 $0.4 \pm 0.4$, 咬合面小裔裂湮 $17.1 \pm 1.9$, 隣接面 0 で合計 $17.5 \pm 2.0$ と sucrose 飼料群 と比較して顕著に低い值を示した。両群間の差は, 頪側 平滑面，咬合面小窝裂清および合計において有意（ $p<$ 0.01) であった。 sucrose 添加のB群の礇蝕スコアを 100 とすると， sorbose 添加のC群は21.3で78.7\%の触抑 制率を認めた。また，第 2 対照群である $56 \%$ starch を

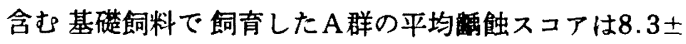
2.4であり，その值を B，C 群から差引き添加した糖に ついて比較すると, sorbose は sucrose に対して $87.6 \%$ の蝕抑制を認めた。なお，Fig. 1 の斜線部分は sorbose 飼料群と比較して sucrose 飼料群の增加した平均 䅘触スコアを示している。

\section{考 察}

砂楉は食生活において広く安定して使用されている主 要な甘味料である。しかし, 近年に至り食品工業上の理 由以外に過剩摄取による肥満や, 糖尿病, 循環器障害の 一因となるなど 砂糖がもつ医学的短所 ${ }^{291}$ が明らかにさ れ，最近における国民の低甘味暂好も相まって，その価 值観に変化がみられている。歯科領域でも砂糖が践触䍜 患に大きな影響を与えていることは周知の事実であり， これらの医学的理由から砂糖に代りうる甘味料が強く望 まれている。現在, 非粫触原性ないし低硧蝕原性糖類と しては sorbitol ${ }^{14-16)}$, xylitol ${ }^{7,15,17)}$, maltitol ${ }^{3,6,18)}$, ery-

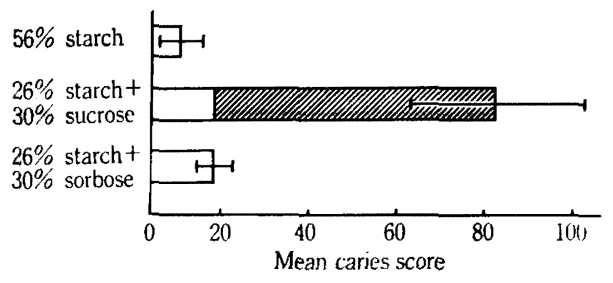

Fig. 1 Mandibular mean total caries score of SPF rats fed with a diet containing sucrose or sorbose

thritol'2) などの糖アルコール類, coupling sugar'), fru ctooligosaccharide $^{13)}$, palatinose ${ }^{19,20)}$ など少糖類および 配糖体である steviosides) などが報告されている。それ らは前述したように甘味度と甘味の澌, 価格あるいは食 品工業的理由などで, 砂糖と比較すればいくつかの劣る 性状をもっている。したがって，食品への利用は他の甘 味料と併用してそれらの欠点を補っているが，用途はあ る程度限定され，より良啠の甘味料が必要と思われる。

Sorbose については，唾液および齿垢を用いての $\mathrm{pH}$ 測定試験 ${ }^{21,80)}$, 非水溶性 glucan $0 の$ 合成性 ${ }^{311}$, Os-

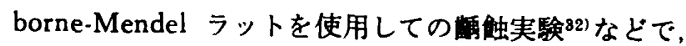
その基質としての蝕原性程度が報告されている。しか し, これらの報告は, 個々の特定因子に対する䠃触原性 を明らかにしたことで意義があるものの，各報告は供試 菌株を含めた実験方法に異りがあり， sorbose の触原 性を総合的に判断するには, 一連の系統的研究が必要と 思われる。本研究は，この目的のため当教室で長年改善 を行ってきた一連の系統的研究方法を使用して, sorbose が sucrose と比較して䟹触になりにくい桾である 証拠を，現在の穤触因論に基ついて検討した。

sorbose は，供試した $S$. mutans 群のすべての血清 型菌株により発育のための炭素源として利用されす，釈 酸生成にも基䋢として利用されず，供武した 7 菌種の口 腔細菌によっても乳䣬へ代謝されなかった。これらの結 果は, Bibby ら ${ }^{30}$ の供試歯垢を $1 \%$ sorbose 溶液に混 
和し20分後の $\mathrm{pH}$ がほとんど変化しなかったことを支 持するものである。さらに，著者らの実輸で S. mutans 群各血清型菌株による人工歯垢形成にも利用されず，血 清型 $d, g, h$ 菌株一の菌体凝集性も認めら九なかった。 なお，供試した BHT 株は歯垢形成能と菌体凝集性を 欠如しており, 血清型 $d, g, h$ 菌株以外の教室保存 $S$. mutans 群菌株も，長年人工的に保存されたためか, 菌 体凝集性を欠如した菌株となっている。また， sorbose は, S. mutans PS-14株 (c) とS. sobrinus 6715株 (g) の GTase により非水溶性 glucan 一生成されず，同物 倎が関与寸る平滑面への本菌体付着にも基梊として利用 されなかった。これらの in vitro 実験結果は, sorbose が基質として非触触性であることを強く示唆してい る。また, sucrose 依存の非水溶性 glucan 生成および平 滑面への菌体付着に対する阻害作用は顥著でなかった。 この結果は Imai ら 311 の報告と類似しており，両阻害作 用は maltose $e^{8)}$, palatinose $e^{20)}$, maltosylsucrose $e^{4,8)}$, lactulose $^{9)}$, nystose ${ }^{13)}$ などの少糖類に認められているの で、単糖類である sorbose にはその明らかな作用がない と思われる。

一方，ラットを用いた in vivo 実験において， sor-

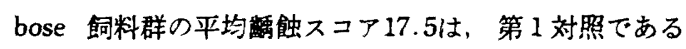
sucrose 飼料群の平均翻蝕スコア 82.1 と比較して, 顕著 に触が抑制（抑制率78.7\%）されその差は有意 $(p<$ 0.01)であった。しかし，同スコアは第 2 対照である sucrose 無添加の starch 飼料群の平均䙵蝕スコア8.3よ りも高かった。このことは, Lohmann ら トに L. casei を感染し sorbose 含有飼料で飼育した実 験において，顕著に螕蝕が誘発されたこと，また， sorbose が L. casei により発醭され乳酸を生成すること, および著者らの発育試験においても sorbose 含有培地で L. casei を18時間培養後 glucose と比較して約 $56 \%$ 程度 の発育が喼められたことなどから、ラット歯垢中の La. ctobacillus 属歯が何らかの影響をおよほしていること も推定される。しかし，実験方法で述べた著者らの同菌 resting cell 用いた乳酸生成試験では sorbose から乳 酸生成が認められていない。また，ヒトにおいては La ctobacillus 属菌の菌垢からの分離頻度はきわめて低く, 触を初発させる原因仙はならないものと考えられてい 万34)。

以上の in vitro およびラット蠤実験結果から, sorbose は非阿触原性に近い低蜆性糖類と判断される。 sorbose は sucrose の80 90\%の甘味度をもち,テイリ ングおよび吸湿性のない熱に安定な 白色の 結晶体であ
る。楉尿病や肥満などに対する低エネルギー甘味料，お よび食品素材 ${ }^{35)}$ （バルキングエージェント）としての用 途開発が行われている。加えて, 非触原性に近い低愿 触原性甘味料としてかなり広筑囲の利用が期待される。

\section{結 論}

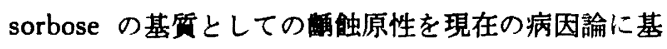
ゔき, 触の主要原因菌である Streptococcus mutans 群および 7 菌種の口腔細菌を用い in vitro と in vivo で実鋣し，次の結果を得た。

sorbose は:

1. 供試した S. mutans 群のすべての血清型 $(a \sim h)$ 菌株によりエネルギー源として利用されず，発育を認め なかった。他の口腔細菌では，Lactobacillus 属菌が多 少の発育を認めた以外, S. mutans 群以外の Streptococcus 属菌, Actinomyces 属菌の供試菌株により発育の ために利用されなかった。

2.S. mutans 群を用いて行った試験管内菌垢形成実 験で, 各血清型菌株とも歯垢の形成は認められなかっ た。また，菌体凝集作用も認めなかった。

3. S. mutans 群の各菌種をはじめ菊垢の優勢菌であ る S. sanguis, S. mitior, A. viscosus, A. naeslundii, 象牙質部触の主要原因菌である L. casei, L. acidophilus, その他 S. salivarius により乳酸への生成は認めら れなかった。

4. S. mutans 群菌株の glucosyltransferase により 非水溶性 glucan への合成は認められなかった。さら に, 同反応が関与する本菌体の平滑面への付着にも基梊 として利用されなかった。

5. S. mutans 群菌株の GTase による sucrose 依存 の非水溶性 glucan 合成と菌体付着を㧕制する作用は, 影著でなかった。

6. ラット触実験において, sorbose 飼料群の平均 触スコアは17.4

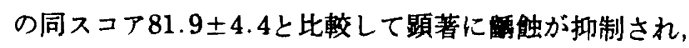
その差は有意 $(p<0.01)$ であった。

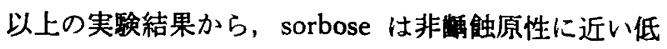
解触原性糖類と認める。

\section{文献}

1) Loesche, W. J.: Role of Streptococcus mu. tans in human dental decay, Microbiol. Rev., $50 ; 353-380,1986$.

2）池田正：触の病因，界展望，74；1107$1115,1989$. 
3）武笠寿彦：Maltitol および SE 58 の非蛊 性楉類としての可能性について, Streptococcus mutans による insoluble glucan の生成とラ ットに対する触誘発性, 日大口腔科学, 3 ; 266-275, 1977.

4) Ikeda, T., Shiota, T., McGhee, J. R., Otake, S., Michalek, S. M., Ochiai, K., Hi. rasawa, M. and Sugimoto, K. : Virulence of Streptococcus mutans: Comparison of the effects of a coupling sugar and sucrose on certain metabolic activities and cariogenicity, Infect. Immun., $19 ; 477-480,1978$.

5) 池田 正, 岡田英子, 元田能一：Streptococcus mutans による stevioside の利用: 発青, 酸産 生および insoluble glucan の生成について, 日大口腔科学, $4 ; 24-27,1978$.

6) 八木精一: Streptococcus mutans の insoluble glucan 生成およびェナメル犋の硬度変化に及

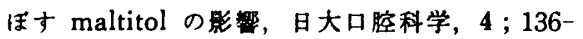
144, 1978.

7) 池田 正, 大竹雄, 渡辺千秋: Xylitol のStreptococcus mutans 菌体付着, 不溶性 glucan 生成一の影㞸拄よび代謝適応性, 日大口腔科 学, 5 ; 202-205, 1979.

8) Ikeda, T.: Sugar substitutes: Reasons and indications for their use, Int. dent. J., 32 ; 33-43, 1982.

9）久保寺徳利：Lactulose の基啠としての触原 性，口腔衛生会誌，33；110-117，1983.

10）池田 正：歯科領域から見た甘味料一う強予防 の立場から一，臨床栄意，71；736-741，1987.

11）節 英司: Polydextrose および精製 polydextroseの基啠としての蚀原性，日大口腔科学， $15 ; 1-11,1989$.

12）川名部淳: Erythritol の基啠としての非䖵原 性, 日大口腔科学, $16 ; 27-36,1990$.

13) Ikeda, T., Kurita, T., Hidaka, H., Michalek, S. M. and Hirasawa, M.: Low-cariogenicity of the tetrasaccharide nystose, Gen. Pharmacol., 21 ; 175-179, 1990.

14) Frostell, G., Keyes, P. H. and Larson, R. H. : Effect of various sugars and sugar sub. stitutes on dental caries in hamsters and rats, J. Nutrit., 93 ; 65-76, 1967.

15) Mühlemann, H. R., Regolati, B. and Marthaler, T. M. : The effect on rat fissure caries of xylitol and sorbitol, Helv. Odontol. Acta, 14 ; 48-50, 1970.

16) Birkhed, D.: Automatic titration method for determination of acid production from sugars and sugar alchohols in small samples of dental plaque material, Caries Res., 12 ; 128-136, 1978.

17) Scheinin, A. and Mäkinen, K. K. (Ed) : Turku sugar studies I-XXI, Acta Odont.
Scand., 33(Suppl. 70) : 5-348, 1975.

18) Rundegren, J., Koulourides, T. and Ericson, T. : Contribution of maltitol and lycasin to experimental enamel demineralization in the human mouth, Caries Res., $14 ; 67-74$, 1980.

19) Maki, Y., Ohta, K., Takazoe, I., Matsukubo, Y., Takaesu, Y., Topitsoglou, V. and Frostell, G. : Acid production from isomaltulose, sucrose, sorbitol, and xylitol in suspensions of human dental plaque, Caries Res., 17 ; 335-339, 1983.

20) Ooshima, T., Izumitani, A., Sobue, S., Okahashi, N. and Hamada, S.: Non-cariogenicity of the disaccharide palatinose in experimental dental caries of rats, Infect. Immun., 39 ; 43-49, 1983.

21) Mühlemann, H. R. and Schneider, Ph. : The effect of sorbose on $\mathrm{pH}$ of mixed saliva and interproximal plaque, Helv. Odontol. Acta, $19 ; 76-80,1975$.

22) Fukushima, K., Motoda, R. and Ikeda, T. : Effects of exogenous insoluble glucan primer on insoluble glucan synthesis by Streptococcus mutans, J. dent, Res., 60 ; 1707-1712, 1981.

23) Ikeda, T., Otake, S., Hirasawa, M., Williams, K., Kiyono, H., McGhee, J. R. and Shiota, T.: Virulence of Streptococcus mu. tans: Revertants of mutant $\mathrm{C} 4$, Infect. Immun., 27 ; 25-31, 1980.

24) Bergmeyer, H. U. (Ed) : Methods of enzymatic analysis, Vol. III Verlg Chemie, Wein. heim, 2 nd English Ed., 1974, 1464-1468.

25) Dubois, M., Gilles, A., Hamilton, J. K., Rebers, P. A. and Smith, F.: Colorimetric method for determination of sugars and re. lated substances, Anal. Chem., 28 ; 350-356, 1956.

26) Schachtele, C. F., Staat, R. H. and Harlander, S. K. : Dextranase from oral bacteria : inhibition of water-insoluble glucan production and adherence to smooth surfaces by Streptococcus mutans, Infect. Immun., 12 ; 309-317, 1975.

27) Bray, G. A. : A simple efficient liquid scintillator for counting aqueous solutions in a liquid scintillation counter, Anal. Biochem., 1 ; 279-285, 1960.

28) Keyes, P. H. and Jordan, H. V.: Periodontal lesions in the syrian hamster-III. Findings related to an infections and transmisssible component, Archs oral Biol., 9 ; 377400, 1964 .

29）関本博，松谷芳英，森本悦司：砂榶捊取と血 
管障害，糖尿病学，彭断と治㾌社，東京，1986， 162-185.

30) Bibby, B. G. and FU, J.: Changes in plaque $\mathrm{pH}$ in vitro by Sweeteners, J. dent. Res., 64 ; 1130-1133, 1985.

31) Imai, S., Takeuchi, K., Shibata, K., Yoshikawa, S., Kitahata, S., Okada, S., Araya, S. and Nisizawa, T.: Screening of sugars inhibitory against sucrose-dependent synthesis and adherence of insoluble glucan and acid production by Streptococcus mutans, J. dent. Res., 63 ; 1293-1297, 1984.

32) Mühlemann, H. R.: The effects of a sorbose/sucrose diet on experimental caries and body weight gains, Helv. Odontol. Acta,
86 ; 1339-1345, 1976.

33) Lohmann, D., Gehring, F. and Karle, E. : J.: Fermentation of L-sorbose by microorganisms of the human dental plaque, Caries Res., 15 ; 263-271, 1981.

34) Ikeda, T., Sandham, H. J. and Bradley, Jr. E. L.: Changes in Streptococcus mutans and Lactobacilli in plaque in relation to the initiation of dental caries in negro children, Archs oral Biol., 18 ; 555-566, 1973.

35) Furuse, M., Tamura, Y., Matsuda, S., Shimizu, T. and Okumura, J.: Lower fat deposition and energy utilization of growing rats fed diets containing sorbose, Comp. Biochem. Physiol., 94A ; 813-817, 1989. 